\title{
EQUAL PROTECTION AND PRISON-TO-HOSPITAL TRANSFERS: UNITED STATES ex rel. SCHUSTER v. HEROLD
}

Until recently a prisoner's "rights" were not rights at all but exceptional privileges which "the law in its humanity accords to him." 1 Today there is growing judicial recognition that "[a] prisoner retains all the rights of an ordinary citizen except those expressly, or by necessary implication, taken from him by law." 2 This changing view of prisoners' rights evolved as a resolution of two competing factors. The first is the understandable reluctance of the courts to interfere with internal prison administration. ${ }^{3}$ The second is the realization that certain constitutional guarantees protect even convicts ${ }^{4}$ and that a judicial duty to define and enforce prisoners' rights is essential to these guarantees. ${ }^{5}$ Courts have proceeded slowly toward defining a middle ground between these positions, intervening only when the infringement of prisoners' rights reached "such a constitutional magnitude" as would justify departure from the general rule of noninterference. ${ }^{6}$ Courts have

I Ruffin v. Commonwealth, 62 Va. (21 Gratt.) 790, 796 (1871).

2 Coffin v. Reichard, 143 F.2d 443, 445 (6th Cir. 1944) ; see, e.g., Price v. Johnston, 334 U.S. 266 (1948) ; People ex rel. Brown v. Johnston, 9 N.Y.2d 482, 174 N.E.2d 725,215 N.Y.S.2d 44 (1961).

For a thorough discussion of prisoners' rights, see Note, Constitutional Rights of Prisoners: The Developing Law, 110 U. PA. L. REv. 985 (1962) [hereinafter cited as Constitutional Rights of Prisoners]. See also Barkin, The Emergence of Correctional Laze and the Awareness of the Rights of the Convicted, 45 NEB. L. REv. 669 (1966) ; Note, The Problents of Modern Penology: Prison Life and Prisoners Rights, 53 Iowa L. REv. 671 (1967) ; Note, Beyond the Ken of the Courts: A Critique of Judicial Refusal to Revieze the Complaints of Convicts, 72 YALE L.J. 506 (1963) [hereinafter cited as Beyond the Ken of the Courts].

3 Some courts have stated the dogma of the independence of prison authorities in language which suggests courts have no jurisdiction to enforce prisoners' rights. In Banning v. Looney, 213 F.2d 771 (10th Cir.), cert. denied, 348 U.S. 859 (1954), for example, the court stated that "courts are without power to supervise prison administration or to interfere with the ordinary prison rules or regulations." This doctrine has been primarily responsible for the lack of redress for state prisoners. To the extent the doctrine prevents review of prisoner deprivations which are necessary concomitants of prison life, it provides a useful method of disposing of frivolous prisoner complaints. But the proposition that courts have no jurisdiction over prisoners' complaints is untenable if it is accepted that prisoners have certain rights and that implicit in such guarantees is a judicial duty to define and enforce those rights. See Beyond the Ken of the Courts, supra note 2, at 506-07; Constitutional Rights of Prisoners, supra note 2 , at $986-87$.

4 See, e.g., Johnson v. Avery, 393 U.S. 483 (1969).

5 See note 3 supra. Until recently, this duty has not been fulfilled. See, e.g., Hatfield v. Bailleaux, 290 F.2d 632 (9th Cir.), cert. denied, 368 U.S. 862 (1961); Eaton v. Bibb, 217 F.2d 446 (7th Cir. 1954), cert. denied, 350 U.S. 915 (1955); United States ex rel. Wagner v. Ragen, 213 F.2d 294 (7th Cir.), cert. denied, 348 U.S. 846 (1954).

${ }^{6}$ Although some courts have suggested that courts "will interfere if the treatment of prisoners amounts to deprivation of [their] constitutional rights," other courts have taken the position that not all infringements of the constitutional rights of prisoners would justify judicial intervention. Compare United States ex rel. Yaris v. Shaughnessy, 112 F. Supp. 142, 144 (S.D.N.Y. 1953), with Nichols v. McGee, 169 F. Supp. 721, 725 (N.D. Cal.), appeal dismissed, 361 U.S. 6 (1959). Recent Supreme 
been most ready to interfere with prison administration in situations involving unreasonable obstruction of access to the courts, infringement of certain first amendment freedoms, or violation of the eighth amendment's prohibition against cruel and unusual punishment. ${ }^{7}$ United States ex rel. Schuster $v$. Herold, ${ }^{8}$ however, is among the first decisions to apply equal protection principles to a state's differing treatment of prisoners and nonprisoners. ${ }^{9}$ In Schuster, the United States Court of Appeals for the Second Circuit held that a New York statute violated the Federal Constitution because it afforded substantially fewer procedural safeguards ${ }^{10}$ to prisoners facing transfer to an institution for the criminally insane than to nonprisoners facing involuntary commitment. ${ }^{11}$ More specifically, the court ruled that a New York prisoner

Court decisions have not attempted a definitive formulation of prisoners' rights. In Johnson v. Avery, 393 U.S. 483, 486 (1969), the Court noted:

There is no doubt that discipline and administration of state detention facilities are state functions. They are subject to federal authorities only where paramount federal constitutional or statutory rights supervene. It is clear, however, that in instances where state regulations applicable to inmates of prison facilities conflict with such rights, the regulations may be invalidated.

See also Cooper v. Pate, 378 U.S. 546 (1964) ; Cochran v. Kansas, 316 U.S. 255 (1942) ; Pierce v. La Vallee, 293 F.2d 233 (2d Cir. 1961).

7 See Constitutional Rights of Prisoners, supra note 2, and cases cited therein.

8410 F.2d 1071 (2d Cir. 1969), cert. denied, 90 S. Ct. 81 (1969). New York state courts first employed equal protection principles to test that state's refusal to grant prisoners facing substantial deprivations of liberty the same procedural safeguards afforded civilians in People v. Fuller, 24 N.Y.2d 292, 248 N.E.2d 17, 300 N.Y.S.2d 102 (1969).

9 In Nichols v. McGee, 169 F. Supp. 721 (N.D. Cal.), appeal dismissed, 361 U.S. 6 (1959), the court held a prisoner's allegation that segregated cells and dining facilities denied Negro prisoners equal protection of the laws "could state no cause of action in this Court." Id. at 724. However, Nichols is no longer the law, for in Lee v. Washington, 390 U.S. 333 (1968), the Supreme Court affirmed a district court's order requiring Alabama to "take the necessary and appropriate steps to desegregate immediately the ... state penal system." 263 F. Supp. 327, 333 (M.D. Ala. 1966). Equal protection there prohibited a state from discriminating among prisoners along racial lines. The decision accords with what one authority has called the "substantive development" of equal protection. Tussman \& tenBroek, The Equal Protection of the Lawe, 37 CALIF. L. REv. 341, 361 (1949). Courts have supplemented the equal protection doctrine of unreasonable statutory classifications "with the assertion that there are some classifications which can never be made no matter how reasonably they may be related to a legitimate public purpose." Id. 354 ; see Developments in the LazEqual Protection, 82 HARv. L. REv. 1065, 1087-1101 (1969).

10 The court held that prisoner patients are entitled to substantially the same safeguards afforded nonprisoners before commitment. "[O]ur decision today does not mean that all distinctions between civilian and prisoner patients must be swept aside." 410 F.2d at 1084. For example, civilians are entitled to a judicial determination not just that they are insane, but that they are dangerously so, before they can be committed to a hospital operated by the Department of Correction. This additional finding, the court suggests, may be inappropriate for prisoner patients who, because they have long penal sentences still to serve, might be more prone to escape and therefore require additional security.

11 In Matthews v. Hardy, No. 22,315 (D.C. Cir., Aug. 29, 1969) (Wright, J.), the District of Columbia's streamlined procedure for prisoner transfers to St. Elizabeth's Hospital was found vulnerable to the same equal protection analysis as was employed in Schuster. D.C. CoDE ANN. \$24-302 (1967) provided that if the Director of Corrections believed a prisoner was mentally ill, he could refer the prisoner to a psychiatrist; and, if the psychiatrist concurred in that belief, the Director could transfer the prisoner to St. Elizabeth's. In order to save the statute from constitutional attack, the court construed it to require that a prisoner be given the same rights to a judicial hearing, jury trial, notice, appointed counsel, cross-examination, and release procedures as was provided in the District's civil commitment statute. 
transferred to a hospital for the criminally insane was entitled to examination by two independent physicians, appropriate notice of a hearing at which he could introduce evidence and cross-examine witnesses, judicial review of the transfer proceedings before his transfer, and periodic reexamination by the state Mental Health Information Service of the need for continued confinement after his transfer. ${ }^{12}$

The decision contributes significantly to the developing law of prisoner rights in two ways. First, it assures to prisoners the availability of whatever safeguards have been instituted for nonprisoners by the states within the Second Circuit's jurisdiction. ${ }^{13}$ While civil commitment procedures in some states may themselves be deficient in affording procedural due process, ${ }^{14}$ their application should appreciably reduce mistaken or punitive prisoner transfers. Second, because the court framed the issue in terms of an unreasonable legislative classification rather than an assessment of the due process requirements of prisoner commitment proceedings, the decision suggests that an equal protection analysis can successfully be used to challenge other unreasonable prison deprivations which do not amount to infringements of other constitutional guarantees. However, if Schuster is to make these contributions, the equal protection principles underlying the decision must be placed on firmer analytic ground.

Roy Schuster was convicted of second degree murder in 1931 and sentenced to a term of twenty-five years to life. After serving ten years, he sought the assistance of counsel in an effort to expose the allegedly corrupt administration of the prison's education program. ${ }^{15}$ Shortly thereafter the prison doctor ${ }^{16}$ examined him and found that his charges evidenced " the paranoid idea that members of the [prison] personnel are against him." "17 Solely upon the certification of this doctor that

12 Compare N.Y. CORREC. LAW $\$ 383$ (McKinney 1968) with N.Y. MENTAL Hygiene Law $\$ \$ 72-74,88$ (McKinney Supp. 1969).

13 For a sampling of representative civil commitment statutes, see $R$. Rock, $M$. Jacobson, \& R. Janopaul, Hospitalization and Discharge of the Mentally Ill (1968); Cohen, The Fanction of the Attorney and the Commitment of the Mentally Ill, 44 TEx. L. REv. 424, 460-66 (1966).

14 See Kittrie, Compulsory Mental Treatment and the Requirements of "Due Process," 21 OнIо Sт. L.J. 28 (1960) ; Ross, Commitment of the Mentally Ill: Problems of Law and Policy, 57 MICH. L. REv. 945 (1959); Comment, Analysis of Legal and Medical Considerations in Commitment of the Mentally Ill, 56 YALE L.J. 1178 (1947).

15 Petitioner's Brief for Certiorari at 4, Herold v. Schuster, 90 S. Ct. 81 (1969); see 410 F.2d at 1075 .

16 There was no evidence that the prison doctor had psychiatric training, nor was there a record of any diagnosis by the Dannemora doctor who examined Schuster before his transfer. Petitioner's Brief for Certiorari at 4, Herold v. Schuster, 90 S. Ct. 81 (1969) (examination before transfer); 410 F.2d at 1076 (no evidence of psychiatric training of prison doctor nor record of diagnosis by Dannemora doctor).

17410 F.2d at 1073. In its brief for certiorari to the Supreme Court the state attempted, by juxtaposing the allegations in Schuster's pro se brief to the Second Circuit and a medical text's description of paranoia, to demonstrate that Schuster presently suffers from this psychotic disorder. Compare Petitioner's Brief for Certiorari at 57a-59a, Herold v. Schuster, 90 S. Ct. 81 (1969), with id. 60a-63a. 
the prisoner was " 'in his opinion insane," " 18 Schuster was transferred in 1941 to Dannemora State Hospital for the Criminally Insane. ${ }^{19}$

Schuster became eligible for parole in 1948 but because the parole board refuses to parole any prisoner from Dannemora, his case was perfunctorily dismissed. ${ }^{20}$ The prisoner repeatedly attempted to obtain from state courts a writ of habeas corpus, charging that he had been transferred as a punitive measure without regard to the state of his mental health. ${ }^{21}$ These attempts were unsuccessful. Undaunted, Schuster initiated a federal habeas corpus petition and won still another hearing. Reaching the Second Circuit on appeal from the district court's dismissal of the writ, he contended that because he had been denied the same procedural safeguards that New York afforded nonprisoners facing commitment to a hospital for the mentally ill, the statute under which he had been transferred violated the equal protection clause. ${ }^{22}$

18410 F.2d at 1075 .

19 For a critical examination of Dannemora, see Special Commrtree on tHe Study of Confinement Procedures and tHe LaW RELATING to INCOMPETENTS, Ass'N of the Bar of the City of New York \& Fordham UNiv. LaW School, Mental Illness, Due Process and the Criminal Defendant 23-26 (1968) [hereinafter cited as N.Y. BAR REPORT]; Morris, The Confusion of Confinement Syndrome: An Analysis of the Confinement of Mentally Ill Criminals and Ex-Criminals by the Department of Correction of the State of New York, 17 BUFF. L. REv. 651 (1968) [hereinafter cited as Morris].

In Dixon v. Attorney General, No. 69-293 (M.D. Pa., filed July 22, 1969), the state has admitted certain facts concerning conditions at Farview State Hospital, a Pennsylvania institution similar to Dannemora. The allegations and admissions are thought to be the first court record establishing the conditions of such institutional life. Farview has over 1,100 inmates, but is staffed by only 31 professionals, including 1 psychiatrist-who does not himself treat inmates-and 5 physicians. Farview has 400 "psychiarty security aids" who function primarily as guards. No more than 2 or $3 \%$ of the inmates at Farview are psychotherapeutically treated; the rest of the inmates receive mainly custodial care. Farview is so situated that it is difficult for the families of inmates to visit a relative at Farview. Complaint at 25-27, Answer at 2, Dixon v. Attorney General, No. 69-293 (M.D. Pa., filed July 22, 1969).

For a discussion of the antitherapeutic value of commitment to Farview, see Note, Hospitalization of Mentally Ill Criminals in Pennsylvania and New Jersey, 110 U. PA. L. REv. 78 (1961) ; Comment, Commitment to Farview: Incompetency to Stand Trial in Pennsylvamia, 117 U. PA. L. REv. 1164 (1969) [hereinafter cited as Commitment to Farviez].

20

While, theoretically, the Parole Board has authority to parole Schuster directly from Dannemora, 1944 Op. Atty. Gen. 117, in practice the Board does not parole anyone who is incarcerated in a mental institution for the presumption is that he is mentally ill.

410 F.2d at 1076 n.3.

Although there is no available evidence to indicate that parole boards in other states systematically refuse to parole hospitalized prisoners, Matthews v. Hardy, No. 22,315 (D.C. Cir. Aug. 29, 1969), suggests this is the practice in the District of Columbia. Judge Wright noted that the District was "unable to assure [the court] that inmates . . would be called for parole hearings and considered for release on parole." Id. at 6-7 (footnote omitted).

21410 F.2d at 1076-77.

22 Brief for Appellant at 3-15, United States ex rel. Schuster v. Herold, 410 F.2d 1071 (1969). 


\section{A. Judicial Review of Prison-to-Hospital Transfers}

If a prisoner is not harmed by transfer to a mental hospital, it is axiomatic that he cannot maintain a suit complaining that the transfer was unlawful. But even if the prisoner can prove he is harmed, his transfer will not be judicially reviewed unless the harm sustained is sufficient to overcome a court's reluctance to enter an area which has generally been thought to be the province of administrative remedies. In Schuster, the Second Circuit found that the consequences of the prison-to-hospital transfer justified judicial intervention.

To be sure, judicial review should not have been a complete surprise. Although courts traditionally have considered transfer from one prison to another, ${ }^{23}$ or from a prison to a mental hospital, ${ }^{24}$ to be an administrative matter immune from judicial review, in People ex rel. Brown v. Johnston, ${ }^{25}$ the New York Court of Appeals reversed the action of a lower court which dismissed a habeas corpus petition requesting review of a prisoner's transfer from a state prison to Dannemora Hospital. The opinion stated that "any further restraint in excess of that permitted by the judgment or constitutional guarantees should be subject to inquiry," ${ }^{26}$ and that habeas corpus was available to determine whether any of the prisoner's rights had been violated. However, Brown did not rule that the transfer from prison to a mental hospital was in fact a "further restraint," but only that a petition for habeas corpus which alleged further deprivation entitled the petitioner to a judicial hearing on the question of "further restraint." 27 There is no reported decision on remand. ${ }^{28}$ Thus Schuster is the first decision to hold that hospitalization did in fact result in greater deprivation than imprisonment.

There is very little empirical evidence by which a court can compare life in a mental hospital with life in a prison. ${ }^{29}$ The Schuster court cited the pro se brief of a convict at a Massachusetts mental hospital for the criminally insane, which compared restraints and rules at the

${ }^{23}$ See, e.g., Kingen v. Kelley, 3 Wyo. 566, 28 P. 36 (1891); cf. Annot., 95 A.L.R. 1455 (1934).

24 See Darey v. Sandritter, 355 F.2d 22 (9th Cir. 1965) ; Urban v. Settle, 298 F.2d 592 (8th Cir. 1962) ; Garcia v. Steele, 193 F.2d 276 (8th Cir. 1951); Rosheisen v. Steele, 193 F.2d 273 '(8th Cir. 1951); Jones v. Pescor, 169 F.2d 853 (8th Cir. 1948); United States $e x$ rel. Gapinski v. Ragen, 152 F.2d 268 (7th Cir. 1945) ; People ex rel. Sacconanno v. Shaw, 4 App. Div. 2d 817, 164 N.Y.S.2d 750 (1957) (apparently overruled by People ex rel. Brown v. Johnston, 9 N.Y.2d 482, 174 N.E.2d 725, 215 N.Y.S.2d 44 (1961)).

259 N.Y.2d 482, 174 N.E.2d 725, 215 N.Y.S.2d 44 (1961).

$26 I d$. at 485,174 N.E.2d at 726,215 N.Y.S.2d at 45.

27 Cf. People ex rel. Cirrone v. Hoffman, 255 App. Div. 404, 8 N.Y.S.2d 83 (1938).

28 Two years after People ex rel. Brozen v. Johnston, Brown attempted to vacate his rape conviction. The opinion does not state whether Brown was in prison or a hospital. People v. Brown, 19 App. Div. 2d 796, 242 N.Y.S.2d 930 (1963).

20 There was evidence, however, that visitation and correspondence rights at Dannemora were more restrictive than at Clinton ' State Prison. 410 F.2d at 1080. 
Massachusetts hospital to those at a Massachusetts prison. ${ }^{30}$ But since the court had no evidence to demonstrate the similarity of the Massachusetts and New York institutions, the brief had little formal evidentiary value. Nevertheless, the court did have some evidence concerning conditions at Dannemora, ${ }^{31}$ and presumed to know something of conditions at New York state prisons. Although one authority has stated that "[1] ife in many [prisons] is at best barren and futile, at worst unspeakably brutal and degrading," ${ }^{32}$ nevertheless the court had sufficient evidence to conclude that the conditions at Dannemora were worse than at New York prisons.

Moreover, there was the "terrifying possibility that the transferred prisoner [might] not be mentally ill at all." 33 The court stated:

Confined with those who are insane, told repeatedly that he too is insane and indeed treated as insane, it does not take too much for a man to question his own sanity and in the end to succumb to some mental aberration. ${ }^{34}$

The prospect of incurring in a mental hospital a disease the facility is intended to cure is sufficiently alarming to help support a proposition that conditions in a mental hospital are worse than those in a prison. Procedural safeguards could assuage such fears by preventing many mistaken or punitive transfers, but Schuster had been given "no meaningful hearing on the issue of his sanity." 35

Perhaps the most tragic consequence of Schuster's transfer was that he thereby became ineligible for parole. ${ }^{38}$ Had he been eligible, Schuster could conceivably have been released twenty-two years prior to the instant decision. The court, however, only alluded to the loss of parole eligibility; it emphasized instead the other injurious effects of the transfer. ${ }^{37}$ The court may not have focused on this problem because parole is generally considered a matter of legislative grace avail-

30410 F.2d at 1080, 1090-91.

31 See N.Y. BAR REPORT, supra note 19; Morris, supra note 19; Dennison v. State, 49 Misc. 2 d 533, 267 N.Y.S.2d 920 (Ct. Cl. 1966), rev'd on other grounds, 28 App. Div. 2d 608, 280 N.Y.S.2d 31 (1967), aff'd 23 N.Y.2d 996, 246 N.E.2d 760, 298 N.Y.S.2d 1002 (1969).

32 The President's Commission on LAW Enforcement and Administration of Justice, The Challenge of Crime in a Free Society 159 (1967).

33410 F.2d at 1078.

34 Id. at 1078.

$35 I d$. at 1073.

36 See note 20 supra.

Moreover, there was evidence that once a patient has remained in a mental hospital for two years or more, he is unlikely to leave except by death. Bloomberg, $A$ Proposal for a Commenity-based Hospital as a Branch of a State Hospital, in J. KATz, J. Goldstern \& A. Dershowitz, Psycho-Analysis, Psychiatry \& the Law 664 (1967); see Commitment to Farview, supra note 19, at 1167.

37410 F.2d at 1080 . While the court only alludes to the loss of parole eligibility in stating the grounds of its decision, it emphasized this factor in discussing the factual background of the case. See id. at 1074-75, 1076. 
able only at the discretion of a state's custodial officials. ${ }^{38}$ But the court need not have relegated parole considerations to a secondary position; it should be enough to say that a rule allowing wide parole board discretion is irrelevant when the administrative act complained of is not the decision whether or not to grant parole. The injury to Schuster was not that he was denied parole, but that he could not even be considered for parole because of the challenged transfer. ${ }^{39}$

The Second Circuit, then, justifiably concluded that the prison-tohospital transfer could not be left to administrative discretion, because it

significantly increased the restraints upon [Schuster], exposed him to extraordinary hardships, and caused him to suffer indignities, frustrations and dangers, both physical and psychological, he would not be required to endure in a typical prison setting. ${ }^{40}$

\section{B. Equal Protection}

\section{Baxstrom v. Herold}

The possible consequences of an erroneous commitment ${ }^{41}$ pointed up the need for procedural safeguards for prisoners being transferred to

38 See, e.g., Dimarco v. Greene, 385 F.2d 556, 563 (6th Cir. 1967) ; Curtis v. Bennet, 351 F.2d 931, 933 (8th Cir. 1965) ; Carson v. Executive Dir., 292 F.2d 468, 469 (10th Cir. 1961); Briguglio v. New York State Bd. of Parole, 24 N.Y.2d 21, 246 N.E.2d 512, 298 N.Y.S.2d 704 (1969). But see United States ex rel. Campbell v. Pate, 401 F.2d 55 (7th Cir. 1968), which held that the relevant facts used to determine parole denial must not be so "capriciously or unreliably" determined that the inmate is deprived of equal protection of the laws.

Certainly there must be some limitations, since no one would suggest that a parole board could deny parole on the basis of an arbitrary factor such as race, without violating the Constitution. But see note 9 supra. The problem, of course, is proving discrimination. See Richardson v. Rivers, 335 F.2d 996 (D.C. Cir. 1964), in which racial discrimination was alleged, but a summary judgment was granted because the "conclusory assertions" did not provide a genuine issue concerning any material fact. Accord, Peterson v. Rivers, 350 F.2d 457 (D.C. Cir. 1965).

39 "Respondent [Schuster] does not contend, as petitioner claims, that he had a right to be paroled. He contends, merely, that he had a right not to be excluded from the class of persons who are so considered." Respondent's Brief in Opposition to Certiorari at 11, Herold v. Schuster, 90 S. Ct. 81 (1969).

However, this distinction between parole denial and eligibility for parole has not been articulated by the courts, and its judicial acceptability remains in doubt. Compare Carson v. Executive Dir., 292 F.2d 468 (10th Cir. 1961), with United States ex rel. Campbell v. Pate, 401 F.2d 55 (7th Cir. 1968).

40410 F.2d at 1078. Another consequence of the transfer mentioned by the court is that under New York law Schuster could not seek to vacate his original conviction by a writ of coram nobis while he remained at Dannemora. There is no evidence, however, that Schuster ever sought to do so. 410 F.2d at 1080 (citing People v. Booth, 17 N.Y.2d 681,216 N.E.2d 615, 269 N.Y.S.2d 457 (1966)).

In Matthews v. Hardy, No. 22,315 (D.C. Cir. Aug. 29, 1969) the Court of Appeals for the District of Columbia emphasized a factor which the Schnster court did not consider: "[A]lthough regrettable, it is a fact that there is a stigma attached to the mentally ill which is different from that attached to the criminal class in general." Id. at 6 . The social position of prisoner-patients, both in the prison community to which they may have to return and in society at large which they must face on release, may be seriously impaired by the label "insane." Although a life prisoner who is ineligible for parole will never have to face society at large, he may be stigmatized by his fellow convicts if he ever returns to prison.

41 Because the procedural safeguards Schuster demanded were designed to prevent mistaken commitment of sane prisoners, the court emphasized throughout its discussion the harm that could be done to a sane individual who is confined with the insane. 
mental hospitals. Thus the court might have based its decision on the grounds that there was deprivation of liberty without due process of law. However, such a rationale would have presented considerably more difficult problems. ${ }^{42}$ The court focused instead on the disparity of treatment between prisoners and nonprisoners. At the time of Schuster's commitment, a prisoner could be transferred to Dannemora on the certification of a single doctor, without a hearing or judicial review. ${ }^{43}$ Commitment of a civilian, however, required the examination of two qualified examiners, notice of commitment proceedings, and a hearing which allowed an opportunity to cross-examine and present evidence. ${ }^{44}$ Relying on Baxstrom $v$. Herold ${ }^{45}$ the court held that this disparity deprived Schuster of the equal protection of the laws. ${ }^{40}$

While the result in Schuster is consistent with Baxstrom, it does not follow as a matter of course. In Baxstrom, the state attempted to

Cf. Dennison v. State, 49 Misc. 2d 533, 537, 267 N.Y.S.2d 920, 924 (Ct. Cl. 1966), rev'd on other grounds, 28 App. Div. $2 \mathrm{~d}$ 608, 280 N.Y.S.2d 31 (1967), aff'd, 23 N.Y.2d 996, 246 N.E.2d 760, 298 N.Y.S.2d 1002 (1969):

The conclusion is inescapable that, although the claimant did become psychotic after several years at [an institution for defective delinquents], the psychosis or the appearance of psychotic symptoms was caused by the nature of his confinement.

42 Not only are the limits of the due process clause difficult to define, but there is a considerable body of precedent rejecting due process challenges to prison-tohospital transfers. See cases cited note 24 sipra. But cf. Specht v. Patterson, 386 U.S. 605 (1967).

One should note that Schuster unsuccessfully contended in the state courts that his transfer lacked procedural due process; because Batstrom had yet to be decided, there was no precedent for an equal protection challenge. See People ex rel. Schuster v. Herold, 15 N.Y.2d 968, 969, 207 N.E.2d 527, 527, 259 N.Y.S.2d 856, 856 (1965).

43410 F.2d at 1080 . The statute pursuant to which Schuster was transferred ch. 32, art. 5, [1909] Consol. Laws of New York 1757-65 (repealed 1965), was replaced by N.Y. CORREC. Law \$383 (McKinney 1968).

44410 F.2d at 1080 . The civilian commitment statute at the time of Schuster's transfer, ch. 395, \$\$72-75, [1933] Consol. Laws of New York 931-35 (repealed 1965), was replaced by N.Y. MeNTAL HyGiene LAW \$\& 72-74, 88 (McKinney Supp. 1969).

45383 U.S. 107 (1966), noted in 12 VIII. L. Rev. 178 (1966); see Comment, Equal Protection and the Commitment of the Insane in Wisconsin, 50 MARQ. L. Rev. 120 (1966).

46 The court held that the disparity between the procedural safeguards afforded prisoners and nonprisoners at the time of Schuster's transfer violated equal protection principles. It went on to order that Schuster be given a hearing to determine whether he should be detained at Dannemora or Clinton State Prison. At this hearing, the Second Circuit required that Schuster be given "substantially the same procedural safeguards" as currently employed in civil commitments. Not only did the Second Circuit rule that the disparity which existed in 1941 between procedural safeguards afforded prisoners and nonprisoners was constitutionally impermissible, it also ruled that the current disparity violated equal protection. $410 \mathrm{~F} .2 \mathrm{~d}$ at $1083-84$. Compare N.Y. Mental Hygiene Laws \$\$ 72-74, 88 (McKinney Supp. 1969) with N.Y. CoRrec. LAw \&383 (McKinney 1968). The court further noted that "[a]lthough the State argued that the prisoner commitment procedures in the federal system are analogous to New York Correction Law $\$ 383$, the validity of those federal procedures is not before us now." 410 F.2d at 1078 n.5. See 18 U.S.C. $\$ 4241$ (1964).

The Second Circuit did not decide whether Schuster could constitutionally be hospitalized absent adequate treatment. However, citing, inter alia, Rouse v. Cameron, 373 F.2d 451 (D.C. Cir. 1966), and Nason v. Superintendent of Bridgewater State Hosp., 353 Mass. 604, 233 N.E.2d 908 (1968), the court suggested that it might recognize a constitutional right to treatment-grounded in either the prohibition against cruel and unusual punishment of the eighth amendment or the due process or equal protection clauses of the fourteenth amendment-if the proper case were before it. 410 F.2d at 1087-89. 
confine a prisoner at Dannemora after the expiration of his penal sentence. ${ }^{47}$ The procedural safeguards afforded those allegedly insane upon expiration of a prison term were similar to those used in civil commitments except that civilians alleged to be insane had the right to a de novo review by jury trial of the question of sanity. The Supreme Court reasoned that the interests of prisoners nearing the end of their prison term were identical to the interests of nonprisoners, for the statutory purpose of preventing erroneous commitments. The Court found that the state's distinction between soon-to-be-released prisoners and civilians was an unreasonable legislative classification, because it treated differently those similarly situated with respect to the purpose of the law. Chief Justice Warren stated for the Court:

Equal protection does not require that all persons be dealt with identically, but it does require that a distinction made have some relevance to the purpose for which the classification is made. . . . Classification of mentally ill persons as either insane or dangerously insane of course may be a reasonable distinction for purposes of determining the type of custodial or medical care to be given, but it has no relevance whatever in the context of the opportunity to show whether a person is mentally ill at all. For purposes of granting judicial review before a jury of the question whether a person is mentally ill and in need of institutionalization, there is no conceivable basis for distinguishing the commitment of a person who is nearing the end of a penal term from all other civil commitments. ${ }^{48}$

The Second Circuit found the Baxstrom rationale broad enough to cover the facts in Schuster. In the court's words:

Baxstrom clearly instructs that the procedures to be followed in determining whether one is committable must be unaffected by the irrelevant circumstance that one is or has recently

47 Johnnie Baxstrom was certified to be insane by a prison doctor while serving a three year penal sentence and was transferred to Dannemora. Pursuant to New York law as it then stood, the Director at Dannemora petitioned the county court, requesting that Baxstrom be civilly committed at the expiration of his penal sentence. Civil commitment of prisoners at the expiration of a penal sentence differed from all other civil commitments. All persons dissatisfied with a civil commitment order could demand a full review by a jury of the determination of their mental illness-all, that is, except those committed at the end of a penal term, who were denied this right. Moreover, a civilian could be committed to hospitals maintained by the Department of Correction only after a judicial finding that the individual was so dangerous that he should not be confined in a civil hospital. But the decision to confine persons civilly committed at the expiration of their penal sentences at a hospital for the dangerously insane or a civil hospital was completely in the hands of administrative officials. The Court held that equal protection demanded that Baxstrom receive the same treatment as those civilly committed.

For the impact of the Baxstrom decision on prisoners' rights, see Morris, supra note 19 , at $670-75$.

48383 U.S. at 111-12 (citation omitted). 
been under sentence pursuant to a criminal conviction, although the fact that one has committed a crime may be relevant to the substantive conclusion that he is mentally ill. ${ }^{49}$

However, the court did not deal with the Supreme Court's emphasis on the fact that Baxstrom was nearing the end of his sentence and thus had his sentence extended indefinitely when he was committed. Baxstrom, the Second Circuit said, teaches that "[w]hether a man should be committed for mental illness has no relevance to the place where he happens to be at the time he becomes ill." "5o While there is broad language in the Baxstrom opinion which can support such a statement, ${ }^{51}$ the Second Circuit's conclusion does not follow without further discussion. Baxstrom holds only that a state may not differentiate in its procedural safeguards between a prisoner nearing the expiration of his penal sentence and all other persons civilly committed. In Schuster, the legislative classification operated to distinguish a prisoner under a life sentence from civilians.

To support its expansive interpretation of Baxstrom, the court cited other cases which extended the Baxstrom rationale to related factual situations. ${ }^{52}$ The court found indistinguishable People $v$. Fuller, ${ }^{53}$ in which the New York Court of Appeals used Baxstrom to hold that convicts alleged to be narcotics addicts could not be required to undergo a special rehabilitation program-involving the possibility of extended sentences-unless they were given a jury trial on the issue of their addiction, as provided for nonprisoners alleged to be addicted. But Fuller dealt with a commitment which could have extended the period of incarceration, and was therefore more like Baxstrom than Schuster. The Fuller court stated that:

[I]f the substantive crime committed is a misdemeanor, the State has the right to deprive the defendant of his freedom for a period of only one year, not three years. After one year

40410 F.2d at 1081.

$50 I d$. at $1083-84$.

51 See, e.g., 383 U.S. at 111:

[T] he State, having made this substantial review proceeding generally available on [the question of sanity], may not, consistent with the Equal Protection Clause of the Fourteenth Amendment, arbitrarily withhold it from some.

62 Bolton v. Harris, 395 F.2d 642 (D.C. Cir. 1968) ; Cameron v. Mullen, 387 F.2d 193 (D.C. Cir. 1967); and People v. Lally, 19 N.Y.2d 27, 224 N.E.2d 87, 277 N.Y.S.2d 654 (1966), extended Baxstrom to those found not guilty by reason of insanity.

People ex rel. Goldfinger v. Johnston, 53 Misc. 2d 949, 280 N.Y.S.2d 304 (Sup. Ct. 1967), held that a youth could not be transferred from a correctional school to an institution for defective delinquents without the safeguards afforded civilians.

Specht v. Patterson, 386 U.S. 605 (1967), held that a convicted sex offender was entitled to a further hearing before he could be sentenced to an indefinite term as dangerous or an "habitual offender and mentally ill". Although Specht referred to Baxstrom, the basis of decision was the due process clause and not the equal protection clause as in Baxstrom.

6324 N.Y.2d 292, 248 N.E.2d 17, 300 N.Y.S.2d 102 (1969). 
he would be entitled to regain his freedom. The justification for the loss of liberty for periods beyond the maximum authorized sentence for the crime must, therefore, rest on some other basis--the program's civil or nonpunitive aspect. The commitment, therefore, does not differ from purely civil commitment proceedings in nature, purpose and effect, and the right to jury must obtain..$^{54}$

The issue presented in Schuster-whether an individual who is already incarcerated for life suffers a further deprivation when he is committed-was not decided.

\section{A Suggested Rationale}

Perhaps to avoid the appearance of fashioning new law, the Schuster court based its decision solely on Baxstrom and later cases which adopted Baxstrom's rationale. Although Schuster discussed some of the relevant policy considerations, the court did not attempt a thorough analysis of equal protection principles as applied to the Schuster facts. If Schuster is to be persuasive to courts in other jurisdictions, this analysis must be supplied.

The standard used to determine whether state legislative classifications violate the equal protection clause may vary with the particular challenged classification. ${ }^{55}$ According to a common formulation, a classification is constitutionally permissible only if it rests "upon some difference which bears a reasonable and just relation to the act in respect to which the classification is proposed ...."56 But however the constitutional standard is stated, "the end result is whether the line drawn is a rational one." 57 Thus in Schuster the issue was whether the line drawn between prisoner and civilian was rational for the purpose of commitment.

$54 I d$. at 305,248 N.E.2d at 22-23, 300 N.Y.S.2d at 109.

55 See, e.g., Shapiro v. Thompson, 394 U.S. 618, 658-63 (1969) (Harlan, J., dissenting) ; Tussman \& tenBroek, The Equal Protection of the Laws, supra note 9, at 353; Note, Equal Protection and the Indigent Defendant: Griffin and Its Progeny, 16 Stan. L. Rev. 394, 399 (1964).

56 Gulf, C. \& S.F. Ry. v. Ellis, 165 U.S. 150, 155 (1897).

In addition, classifications must serve some legitimate state purpose. See, e.g., Truax v. Raich, 239 U.S. 33. 42 (1915) ; Developments in the Law-Equal Protection, supra note 9, at 1081. The legitimacy of the state's purpose- to determine which of those allegedly insane prisoners is in fact mentally ill and in need of hospitalizationwas, of course, not questioned.

57 Levy v. Louisiana, 391 U.S. 68, 71 (1968).

In general, legislative classifications must bear some reasonable relationship to the statutory purpose. But where the rights in question are so fundamental that the state must prove a "compelling state interest" to justify any interference with those rights, "the issue is not whether the legislative judgments are rational, A more exacting standard obtains." Kramer v. Union Free School Dist. No. 15, 395 U.S. 621, 633 (1969). This Comment does not discuss whether a special equal protection standard might apply to the Schuster situation, since even under the traditional test Schuster was denied equal protection. 
Two reasons can be suggested to justify the statutory distinction. The first is that criminals are more likely to be insane than noncriminals, and, therefore, less stringent precautions need be taken when deciding whether to commit them. ${ }^{58}$ As Schuster recognized, crimes, as abnormal acts, may be relevant to the substantive conclusion that a prisoner is mentally ill. ${ }^{59}$ However, even if criminals as a class are more likely to be insane than civilians-a proposition neither logically compelled nor empirically verified ${ }^{60}$ - the average criminal and the average civilian are not the individuals to whom the differing commitment procedures are applied. Rather, commitment procedures apply to those persons within these larger classifications who have exhibited abnormal behavior and are alleged to be insane. When a civilian and a prisoner, both of whom have exhibited abnormal behavior, are compared, it is considerably more speculative, if not wholly inaccurate, to say that the prisoner is more likely to be insane than the nonprisoner.

Furthermore, assuming arguendo that the allegedly insane criminal is more likely to be insane than his civilian counterpart, this higher

58 See Mathews v. Hardy, No. 22,315, at 5 n.11 (D.C. Cir. Aug. 29, 1969).

This argument is perhaps also suggested by the state's contention in Baxstrom:

[The state] argues that it is reasonable to classify persons in Baxstrom's class together with those found to be dangerously insane since such persons are not only insane but have proven criminal tendencies as shown by their past criminal records.

383 U.S. at 114. The Supreme Court rejected this contention as "untenable." Id. The Court stated:

Classification of mentally ill persons as either insane or dangerously insane of course may be a reasonable distinction for purposes of determining the type of custodial or medical care to be given, but it has no relevance whatever in the context of the opportunity to show whether a person is mentally ill at all. [For this purpose] . . . there is no conceivable basis for distinguishing the commitment of a person who is nearing the end of a penal term from all other civil commitments.

Id. at 111-12. Furthermore, the Court pointed out that

[a] person with a past criminal record is presently entitled to a hearing on the question whether he is dangerously mentally ill so long as he is not in prison at the time civil commitment proceedings are instituted. Given this distinction, all semblance of rationality of the classification, purportedly based on criminal propensities, disappears.

Id. at 115 .

50 "[T] he fact that one has committed a crime may be relevant to the substantive conclusion that he is mentally ill." 410 F.2d at 1081.

60

Unless we can say with assurance that commission of a crime is a highly reliable indicator of mental illness, prior criminal conduct cannot justify aborting the full judicial inquiry into the question of mental illness. Since we have not been referred to any authority which indicates such a close nexus between criminal conduct and mental illness, and since there is no indication that Congress made such a determination when it enacted [the challenged statute], we think that to distinguish between criminais and non-criminals, denying to the former the very important safeguards which insure a full and fair hearing on the issue of mental illness would be arbitrary.

Matthews v. Hardy, No. 22,315, at 5-6 n.11 (D.C. Cir. Aug. 29, 1969).

Insanity only seldom manifests itself in criminal conduct. It is estimated that 18 million people in the United States are suffering from some form of mental illnessabout one in every 10 persons. N.Y. DeP'T OF MENTAL HyGIENE, Hospitalization fOR MENTAl Illness IN New YoRK STATE (1965) (pamphlet). 
probability should not be the basis for treating differently the prisoner and the nonprisoner. It may be true that if slightly less stringent procedures were used to determine the sanity of prisoners, the percentage of incorrect judgments would be substantially the same as in the case of nonprisoners. However, not only is it impossible to determine how much the procedures could differ and still result in the same number of mistaken commitments, but this type of callous "mistake equalization" is an unacceptable rationale for establishing procedures by which individuals are adjudged insane and hospitalized for long periods of time. Rather than building mistakes into the system, a court should not be satisfied if the percentage of mistaken commitments is the same for both prisoners and nonprisoners; it should require instead that an equal effort be made, by the best procedures available, to protect both prisoners and nonprisoners against erroneous determinations of insanity. ${ }^{61}$ In other words, the equal protection clause requires that an equal effort be made to eliminate mistaken commitments-not that an equal number of mistakes be made.

A second reason has been proposed for differing insanity-determination procedures. In its brief for certiorari to the Supreme Court requesting review of Schuster, the state argued that "[i]t is in no sense arbitrary to differentiate between those whose detention results from a valid criminal conviction, and someone whose life is interrupted solely by virtue of a determination that he is mentally ill . . . ." ${ }^{2}$ More directly, the state's argument was that incarceration in a mental hospital is not as great a hardship for a prisoner who would otherwise be imprisoned as is mistaken hospitalization for a nonprisoner who would otherwise be free. ${ }^{63}$ Therefore, fewer safeguards are needed to protect prisoners from error than are needed to protect nonprisoners. This contention is unpersuasive for two reasons. First, if the prisoner loses the possibility of parole, he may have as many years of liberty at stake in an insanity determination as does the noncriminal. Second, the argument above applies here with equal force-an equal effort should be made to protect both prisoners and nonprisoners against erroneous determinations of insanity, using the best procedures available.

Neither of the arguments above provides a "reasonable and just" rationale for employing less stringent procedural safeguards in prisoner

61 Cf. Matthews v. Hardy, No. 22,315, at 5 n.11 (D.C. Cir. Aug. 29, 1969) :

The point here is simply that the judicial procedures in the [civil commitment statute] were designed to afford the fullest possible ventilation of the question whether a person is mentally ill. (1969).

62 Petitioner's Brief for Certiorari at 18-19, Herold v. Schuster, $90 \mathrm{~S}$. Ct. 81

63

As to persons generally, Congress has erected ... a full system of procedural safeguards [to determine the propriety of their commitment]... The appropriate question here is whether incarceration in a mental hospital is sufficiently different from incarceration in a prison to require the same or similar safeguards.

Matthews v. Hardy, No. 22,315, at 6 (D.C. Cir. Aug. 29, 1969). 
commitment proceedings than in civil involuntary commitments, nor can more persuasive arguments be found. Thus, because the line drawn between prisoners and nonprisoners is unreasonable, prisoners are denied the equal protection of the law.

\section{CONCLUSION}

Schuster will have its most immediate impact on commitment procedures for prisoners in New York. Exactly how much it will affect transfer procedures in other jurisdictions will depend on the procedural safeguards afforded by civil commitment statutes in those states in which Schuster is followed.

But more important than this immediate impact is the equal protection analysis Schuster contributes to the developing law of prisoners' rights. If, as Schuster holds, criminality is not a constitutionally permissible distinction for the purpose of defining procedures to determine sanity, many unreasonable prisoner deprivations, hitherto unassailable, may also be vulnerable to an equal protection challenge. 